\title{
Volatile Constituents and Toxicity Profile of the Leaves, Stem Bark and Root Bark Essential Oils of Holarrhena Floribunda and Crescentia Cujete
}

\author{
Sherifat A. Aboaba ${ }^{1}$, Gbenro F. Fasimoye ${ }^{1}$
}

${ }^{1}$ Department of Chemistry, University of Ibadan, Ibadan, Nigeria

\begin{abstract}
Essential oils are highly concentrated substances extracted from flowers, leaves, stems, roots, seeds, barks, resins, or fruit rinds. The increased interest in creating a compendium of plant essential oils for the purpose of discovering drugs from natural source led to the characterization of the leaves, stem bark and root bark of Holarrhena floribunda and Crescentia cujete. The essential oils from the plants parts were extracted by means of hydrodistillation using an all glass Clevenger apparatus while the chemical constituents were determined by Gas Chromatography-Mass Spectroscopy technique. The toxicity of the essential oils was tested using Brine shrimps (Artemia salina). The GC-MS results identified 5, 8, and 7 components in $H$. floribunda (leaves, stem bark and stem bark respectively) while leaves, stem bark and root bark of $C$. cujete had 15, 11 and 10 constituents respectively. The compounds found in high quantity in the essential oils of $H$. floribunda are friedelan-3-one (22.85\%), sesquirosefuran $(31.93 \%)$, octadec-9-enoic acid $(46.28 \%)$, and longifolene $(59.77 \%)$ while the major components in the oils of $C$. cujete are cyclotetradecane $(13.75 \%)$, diisooctylphthalate $(33.96 \%)$, and phytol $(46.33 \%)$. $\mathrm{The} \mathrm{LC}_{50}$ value ranged from 10.85 to $288.76(\mu \mathrm{g} / \mathrm{mL})$ which was a pre-test for toxicity potential. The essential oils of $C$. cujete stem bark, $C$. cujete root bark and $H$. floribunda root bark were the most toxic with $\mathrm{LC}_{50} 10.85,16.54$ and 36.33 $\mu \mathrm{g} / \mathrm{mL}$ respectively. The level of toxicity of these essential oils is an indication of the pharmacological properties the plants may possess.
\end{abstract}

Keywords: Essential oil, Crescentia cujete, Holarrhena floribunda, Longifolene, Toxicity

\section{INTRODUCTION}

Holarrhena floribunda, also known in English as False rubber tree, belongs to the family Apocynaceae (Letouzy, 1972). It is known as ire-oju-ona in Yoruba, gaman sauwa in Hausa and $m b a$ in Igbo (Nigeria). It is a tree or shrub about $17 \mathrm{~m}$ high. It is widely distributed in the centre and west regions of Cameroon. The stem bark is used in Cameroon to treat various ailments such as abdominal pains, nausea, indigestion and diarrhea (Berhaut 1971). The stem bark of $H$. floribunda is febrifuge and could be a quinine substitute, since it showed remarkable inhibitory activity against drug-resistant strains of Plasmodium falciparum (Fortie et al., 2006). This plant has been found to display a wide spectrum of biological and pharmacological activities such as antibacterial (Bogue et al., 2007), analgesic (Udobre et al., 2014), hypoglycemic (Gnangoran (2012) and antiamiboedal (Goutarel (2012).

The common calabash tree (Crescentia cujete) is of the Curcubitaceae family and has been cultivated widely throughout the new world tropics since prehistoric times; its exact native range is uncertain. It is a small tree with light green bell-shaped flowers (5 to $6.5 \mathrm{~cm}$ long) that are borne singly on stout stalks on the trunk and branches. The flowers are batpollinated and are produced irregularly throughout the year. The large fruit has a thin hard shell and whitish pulp and does not split open. The many seeds are dark brown, thin, and flat. Like some other fruits of species in the family Bignoniaceae, the fruits of this species possess nectar-producing nectaries. In some other species in this family, these nectaries have been shown to attract ants that drive away animals that feed on the plants (Elias, 1978). Ejelonu et al. 2011 investigated the proximate composition of C. cujete and found out that the value of the fat, protein, nitrogen, crude fibre, moisture content, sucrose, fructose, galactose and energy content were quite high. Nandita et al. 2014 also investigated the antioxidant properties of the ethanol extracts and fractions of leaves and stem bark and reported the stem bark as having the highest antioxidant activity.

This article is published under the terms of the Creative Commons Attribution License 4.0

Author(s) retain the copyright of this article. Publication rights with Alkhaer Publications.

Published at: http://www.ijsciences.com/pub/issue/2018-02/

DOI: 10.18483/ijSci.1529; Online ISSN: 2305-3925; Print ISSN: 2410-4477 
This paper explores the characterisation of the chemical constituents and toxicity profile of the essential oils of $H$. floribunda and $C$. cujete in continuation of our studies to create a compendium of Nigerian plant essential oils.

\section{Experimental}

Plant collection and preparation.

The leaves, stem bark and root bark of H. Floribunda and $C$. Cujete were collected in March, 2016 from the Botanical Garden, University of Ibadan, Ibadan, Nigeria. The samples were identified at the Herbarium, Botany department, University of Ibadan, Ibadan by Mr. Donatus.

The fresh samples were air-dried and pulverized then stored in air-tight polythene bags prior to extraction.

\section{Isolation of essential oils}

Hydro-distillation was carried out using an all-glass Clevenger apparatus for the extraction of the essential oils. Exactly $200 \mathrm{~g}$ of each of the pulverized samples was weighed and carefully placed in a $5 \mathrm{~L}$ round bottom flask and water was added until the sample was fully immersed. The extraction process was then carried out for each of the weighed sample for 3 hours according to the British pharmacopoeia specification (1980). The sample vial was then stored in the refrigerator at $4{ }^{\circ} \mathrm{C}$ until further analysis.

\section{Gas Chromatography-Mass Spectroscopy (GC- MS) Analysis.}

The essential oils were analysed using GC-MS Agilent 7890A gas Chromatograph coupled with MS Agilent Technologies 5975 series MSD. The capillary column type was an HP-5ms with column length $30 \mathrm{~m}$; internal diameter $0.25 \mathrm{~mm}$ and $0.25 \mu \mathrm{m}$ film thickness. The carrier gas was helium at constant flow rate of $1 \mathrm{~mL} / \mathrm{min}$. The initial column temperature was set at $60^{\circ} \mathrm{C}$ for 2 mins and was then increased at the rate of $10^{\circ} \mathrm{C} / \mathrm{min}$ to $240^{\circ} \mathrm{C}$ for 6 mins.

\section{Identification of the constituents}

The constituents of the essential oils were identified by comparing their retention times with an analysis done under the same temperature-programmed conditions for $n$-alkanes and the oil under the same chromatographic conditions. Individual compounds were identified by comparing their mass spectra with the internal reference mass spectra library or with authentic compounds. Confirmation of identity was done by comparing their retention times with the GCMS and mass spectra from literature data (Adams, 2007; Joulain and Koenig, 1998).

\section{Brine shrimp assay}

Sea water was collected from the ocean in Lagos State, South West, Nigeria. The shrimps (Artemia salina) were purchased from Felimar Aquaculture Centre, Ijebu-ode, Ogun State (produced by Coppens International, Helmond, Holland). Sea water (200 $\mathrm{mL}$ ) was put in a tank or hatching chamber and shrimp eggs added. The tank or hatching chamber was a plastic bowl, partitioned in to two compartments. The partition was perforated such that the nauplii could swim through to the other side after hatching. The eggs were allowed to hatch for $48 \mathrm{~h}$ and mature as nauplii at room temperature. The nauplii were then harvested with a pipette after attracting the organism to one side of the vessel with a touch-light source.

The essential oils were prepared in sea water into vials at 1000,100 , and $10 \mu \mathrm{g} / \mathrm{mL}$ (each test in triplicates). The essential oils had been previously dissolved in $2 \mathrm{~mL}$ of Dimethylsulfoxide (DMSO) since they are not soluble in water and $0.5 \mathrm{~mL}$ each of the dose level were introduced in a test-tube to which $4 \mathrm{~mL}$ of sea water added. Exactly 10 shrimps per test tube were added for each concentration and made up to $5 \mathrm{~mL}$ seawater to make $1000-10 \mu \mathrm{g} / \mathrm{mL}$ of final concentration of extract. After $24 \mathrm{~h}$, the number of deaths over the number of total shrimps (survivors) was counted and recorded. The concentration killing fifty percent of the larvae $\left(\mathrm{LC}_{50}\right)$ was determined.

\section{RESULTS AND DISCUSSION}

The percentage yields of the essential oils are presented in table 1 . The yields were calculated based on volume of essential oil to weight of dry plant sample

(v/w).

Table 1: Percentage yields of the essential oils.

\begin{tabular}{lllc}
\hline S/N & Plant Sample & Mass of Sample $(\mathrm{g})$ & Yield of Oil (v/w) (\%) \\
\hline 1. & HFL & 200 & 0.55 \\
2. & HFS & 200 & 0.39 \\
3. & HFR & 200 & 0.63 \\
4. & CCL & 200 & 0.63 \\
5. & CCS & 200 & 0.71 \\
6. & CCR & 200 & 0.45 \\
\hline
\end{tabular}

HFL = Holarrhena floribunda leaf, HFS = Holarrhena floribunda Stem bark

HFR = Holarrhena floribunda root bark

$\mathbf{C C L}=$ Crescentia cujete Leaf, $\mathbf{C C S}=$ Crescentia cujete Stem bark

$\mathbf{C C R}=$ Crescentia cujete root bark 
Table 2: Chemical Composition of the essential oils of Holarrhena floribunda and Crescentia cujete.

CONSTITUENTS

\begin{tabular}{|c|c|c|c|c|c|c|c|c|c|}
\hline & & & & HFL & HFS & HFR & CCL & CCS & CCR \\
\hline$\Gamma$ & 11.15 & $\alpha$-1onone & & - & - & 5.74 & & 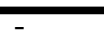 & \\
\hline 2. & 12.39 & (E)- $\beta$-ionone & & - & - & - & 9.41 & - & - \\
\hline 3. & 14.63 & Farnesene & & - & - & - & - & - & 1.48 \\
\hline 4. & 15.61 & $\tau$-muurolol & & - & 11.73 & - & - & - & - \\
\hline 5. & 15.93 & Longifolene & & - & 59.77 & - & - & - & - \\
\hline 6. & 15.94 & $\begin{array}{l}\text { (1S,4aS,7R,8aS)-1, } \\
\text { 4a-dimethyl-7- } \\
\text { (prop-1-en-2-yl) } \\
\text { decahydronaphthalen1-ol }\end{array}$ & & - & - & 17.96 & - & - & - \\
\hline 7. & 16.67 & 2,6,10-trimethyltridecane & - & 3.57 & - & - & - & - & \\
\hline 8. & 18.43 & Hentriacontane & - & - & - & - & 4.74 & - & \\
\hline 9. & 18.56 & Phytane & - & 3.40 & - & 2.30 & - & 9.31 & \\
\hline 10. & 18.58 & 6-methyl-tridecane & & - & - & - & - & 11.46 & - \\
\hline 11. & 19.29 & Hexahydrofarnesyl acetone & & - & - & - & 5.62 & - & - \\
\hline 12. & 20.73 & $\begin{array}{l}\text { 7,9-di-tert-butyl- } \\
\text { 1-oxaspiro }(4,5) \\
\text { deca-6,9-diene-2,8-dione }\end{array}$ & - & - & - & 3.84 & - & - & \\
\hline 13. & 20.76 & Hexadecanoic acid & & - & - & 15.86 & - & - & - \\
\hline 14. & 20.87 & Dodecanoic acid & - & - & 0.96 & - & - & - & \\
\hline 15. & 21.09 & Isophytol & & - & - & - & 1.88 & - & - \\
\hline 16. & 22.63 & $\begin{array}{l}2,4,4,6,6,8,8, \text { heptamethyl } \\
\text {-1-nonene }\end{array}$ & & - & - & 2.00 & 9.36 & 9.92 & \\
\hline 17. & 22.64 & Friedelan-3-one & - & - & 22.85 & - & - & - & \\
\hline 18. & 22.95 & Heptadecanolide & 11.29 & - & - & - & - & - & \\
\hline 19. & 23.41 & Lupeol & & - & - & 1.64 & - & - & - \\
\hline 20. & 23.59 & Sesquirosefuran & - & - & 31.93 & - & - & - & \\
\hline 21. & 23.79 & Phytol & & - & - & - & 46.33 & - & - \\
\hline 22. & 24.01 & 4-methyl octadecane & & - & - & - & 5.27 & - & - \\
\hline 23. & 24.25 & Cyclotetradecane & - & - & - & 3.76 & - & - & \\
\hline 24. & 24.64 & (Z)-p-menth-8(10)-ene-9-o & & - & - & - & - & 2.25 & - \\
\hline 25. & 24.65 & 1-iodo-dotriacontane & & - & - & - & 1.92 & - & - \\
\hline 26. & 26.51 & Eicosane & & - & - & - & - & - & 10.61 \\
\hline 27. & 26.52 & (E)-9-Octadecenoic acid & - & - & - & - & 4.51 & - & \\
\hline 28 . & 27.15 & Octadecene & & - & - & - & - & 3.28 & - \\
\hline 29. & 27.19 & 3-methyl heptadecane & & - & - & - & 1.08 & - & - \\
\hline 30. & 27.70 & $\begin{array}{l}\text { 1,2-benzisothiazole, } \\
\text { 3-(hexahydro-1H-azepin } \\
\text {-1-yl)1,1-dioxide }\end{array}$ & & - & - & 5.44 & - & - & - \\
\hline 31. & 27.71 & (E) -9- eicosene & - & - & - & 3.02 & - & - & \\
\hline 32. & 27.72 & (E)-15-heptadecenal & & - & - & - & - & 12.77 & - \\
\hline 33. & 27.73 & $\begin{array}{l}\text { 10-methylundec-2-en-4- } \\
\text { olide }\end{array}$ & - & - & - & - & - & 5.97 & \\
\hline 34. & 27.74 & 1-bromo-11-iodoundecane & & 2.85 & - & - & - & - & \\
\hline 35. & 27.75 & 2-nitrofuran & & - & - & - & - & - & 7.43 \\
\hline 36. & 27.98 & 1-(ethenyloxy)-octadecane & 8.44 & - & - & - & - & - & \\
\hline 37. & 28.02 & n-propyl-11-octadecenoate & e17.57 & - & - & - & - & - & \\
\hline 38. & 28.03 & $\begin{array}{l}\text { 2-heptenoic acid, } \\
\text { hexadecylester }\end{array}$ & - & 5.02 & - & - & - & - & \\
\hline 39. & 28.08 & 5-cyclohexadecen-1-one & 12.23 & - & - & - & - & - & \\
\hline 40. & 28.17 & 2-methyl-7-nonadecene & - & - & - & - & 0.82 & - & \\
\hline 41. & 28.20 & $\begin{array}{l}\text { Methyl 5,9-hexadeca- } \\
\text { dienoate }\end{array}$ & & - & - & - & - & 1.82 & - \\
\hline 42. & 28.25 & Octadec-9-enoic acid & & 46.28 & - & - & - & - & - \\
\hline 43. & 29.33 & Eicosane & & - & - & - & 1.87 & - & - \\
\hline 44. & 29.34 & Cycloeicosane & & - & - & - & - & - & 11.91 \\
\hline 45. & 29.36 & Nanocosane & & - & 6.05 & - & - & - & - \\
\hline 46. & 30.23 & Diisooctylphthalate & & - & 6.16 & - & - & 33.96 & 20.21 \\
\hline
\end{tabular}




\begin{tabular}{|c|c|c|c|c|c|c|}
\hline 30.24 & Bis(2-ethylhexyl)phthalate & - & - & 4.00 & - & - \\
\hline 30.28 & 1,4- benzendicarboxylic & - & - & - & - & 6.09 \\
\hline 33.56 & Cyclotetradecane & - & - & - & - & 13.75 \\
\hline 33.57 & (E)-9-eicosene & - & - & - & 8.50 & - \\
\hline
\end{tabular}

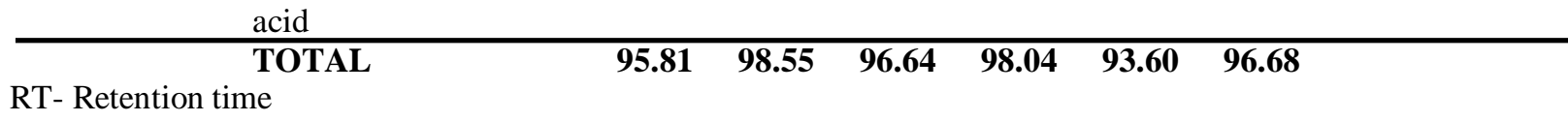

Table 3: Brine Shrimp Toxicity Assay of the Essential Oils Holarrhena floribunda and Crescentia cujete.

\begin{tabular}{llll}
\hline Essential oil & $\mathrm{LC}_{50}(\mu \mathrm{g} / \mathrm{mL})$ & $\mathrm{UCL}(\mu \mathrm{g} / \mathrm{mL})$ & $\mathrm{LCL}(\mu \mathrm{g} / \mathrm{mL})$ \\
\hline HFL & 277.50 & 465.04 & 187.14 \\
$\mathrm{HFS}$ & 257.05 & 429.12 & 172.07 \\
HFR & $\mathbf{3 6 . 3 3}$ & 52.04 & 16.07 \\
CCL & 288.76 & 483.63 & 194.87 \\
CCS & $\mathbf{1 0 . 8 5}$ & 15.70 & 4.85 \\
CCR & $\mathbf{1 6 . 5 4}$ & 19.93 & 3.39
\end{tabular}

$\mathrm{UCL}=$ Upper confidence limit

$\mathrm{LCL}=$ Lower confidence limit

The GC-MS of H. floribunda leaf essential oil led to the characterization 5 constituents representing $95.81 \%$ of the total oil. The oils were dominated by non-terpene compounds, these are; heptadecanolide (11.29\%), 1-ethenyloxy-octadecane $(8.44 \%)$, npropyl-11-octadecenoate $\quad(17.57 \%)$, cyclohexadecen-1-one (12.23\%) and octadec-9-enoic acid $(46.28 \%)$, in addition, 8 compounds was characterized in the stem bark oil and dominated mainly by sesquiterpene compounds; $\tau$-muurolol $(11.73 \%)$ and longifolene $(59.77 \%)$ while the root bark afforded the characterization of 7 compounds with sesquirosefuran (31.93\%), friedelan-3one $(22.85 \%) \quad(1 \mathrm{~S}, 4 \mathrm{aS}, 7 \mathrm{R}, 8 \mathrm{aS})-1, \quad$ 4a-dimethyl-7(prop-1-en-2-yl) decahydronaphthalen1-ol (17.96\%) and hexadecanoic acid $(15.86 \%)$ being the major compounds.

$\tau$-muurolol, a sesquiterpenoid has been isolated from the marine Streptomyces sp. M491(Ding et al. 2009). Nii et al., 1982 found longifolene and sesquirofuran as the major constituents of the essential oils from Actinodaphna lancifolia Meisn. fruits, roots and leaves, Bourgou et al., 2010 reported longifolene as a major compound detected in the bioactive essential oil of black cumin while Sousa et al, 2012 isolated the triterpene, friedelan-3-one as one of Chenopodium ambrosiodes Lineu. and Kielmeyen neglecta Sadd. Octadecanoic acid (oleic acid) likewise has been detected in high quantity in the leaf oil of Prasium majus from Croatia (Jerkovic et al., 2012). All the mentioned constituents were also reported to possess various activities (Ding et al., 2009; Nii et al., 2008; Bourgou and Legault, 2010; Souza et al., 2012; Jerkovic et al., 2012.

The characterisation of the leaf oil of $C$. cujete afforded the identification of 15 compounds representing $98.04 \%$ and was dominated by a diterpenoid phytol $(46.33 \%)$. Phytol has been found in appreciable amount in plant essential oils (Jia et al., 2008; Aboaba and Udom, 2013). The stem bark oil had 11 components mainly non-terpenes. A high proportion of the oil had diisooctylphthalate (33.96\%), (E)-15-heptadecenal $(12.77 \%)$ and 6methyl-tridecane $(11.46 \%)$ while the root oil of $C$. cujete was constituted by 10 compounds representing $96.68 \%$ of the entire oil. A sesquiterpene, farnesene $(1.48 \%)$ was present in the oil. Other compounds were essentially non-terpene compounds. A high quantity of diisooctylphthalate was present in the essential oil of Eaglewood tree (Aquilaria agallocha Roxb.) and was suggested as a natural source of the compound as it contained $71.97 \%$ of diisooctylphthalate (Bhuiyan et al., 2009)

In the present study the brine shrimp lethality of essential oil of leaves, stem bark and root bark of $H$. floribunda and $C$. cujete used in traditional medicine was tested against Artemia salina (Brine Shrimp). The result showed that oil from leaves, stem bark and root bark of $H$. floribunda and $C$. cujete was found to be toxic (Table 3 ) since all the six oils exhibited toxicity level less than $500 \mu \mathrm{g} / \mathrm{mL}$. The brine shrimp lethality assay represent a rapid, inexpensive and simple bioassay for testing plant oil bioactivity which in most cases correlates reasonably well with cytotoxic and anti-tumor properties (Gang et al., 2001).

The $\mathrm{LC}_{50}$ values of the brine shrimp obtained for essential oil of these medicinal plants as shown in table 3 reveals that the essential oil of $C$. cujete stem bark, $C$. cujete root bark and $H$. floribunda root bark has the most prominent activity with $\mathrm{LC}_{50} 10.85$, 16.54 and $36.33 \mu \mathrm{g} / \mathrm{mL}$. Therefore, using these oils at higher concentration should be well monitored. The high toxicity can be beneficial in the therapy of some ailments involving cell or tumour growth. It has finally been found out that medicinally active natural products are most toxic to brine shrimp (Artemia salina) nauplii (Onocha, 1995). 


\section{CONCLUSION}

We have characterized the essential oils from the leaf, stem bark and root bark of $H$. floribunda and $C$. cujete from South west Nigeria and to the best of our knowledge, the first report from that region. The abundance of some of the characterised compounds in the studied essential oils may be explored for natural sources of such compounds. The level of toxicity exhibited by some of the plant essential oils as shown above is an indication they could be useful sources of bioactive agents.

\section{CONFLICT OF INTEREST}

\section{None declared}

\section{REFERENCES}

1. Aboaba, S. A and Udom, I. E (2013) Chemical assessments of Eremomastax speciosa and Lasianthera Africana leaf essential oil. Journal of Science Research. 12: 63-71.

2. Nandita, D., Nusrat, J., Alam, K., Shahnaj, P., Ekramul, I., Mohammad, S and Rafikul, I (2014). Antioxidant activities of ethanol extracts and fractions of Crescentia cujete leaves and stem bark and the involvement of phenolic compounds. BMC Complementary and Alternative Medicine. 14: 45

3. Adams, R. P (2007). Identification of essential oil components by gas chromatography/quadrupole mass spectrometry, $4^{\text {th }}$ ed., Allured publishing, Carol Stream, IL.

4. Berhaut, J (1971). Flore illustrée du Sénégal Gouvernement du Sénégal Ministère du Développement Rural, Direction des Eaux et Forêts DAKAR, pp. 385-386.

5. Bhuiyan, M. I., Begum, J and Bhuiyan, M. (2009). Analysis of essential oil of eaglewood tree (Aquilaria agallocha Roxb.) by gas chromatography mass spectrometry. Journal of the Bangladesh Pharmacological Society (BDPS). 4: 24-28. Doi: 10.3329/bjb.v4i1.851.

6. Bogne, K.P., Penlap, B. V., Lontsi, D and Etoa, F (2007). Antibacterial activities of the extracts and conessine from Holarrhena floribunda G. Don (Apocynaceae). African Journal of Traditional, Complementary and Alternative Medicines. 4: 352-356.

7. Bourgou, S and Legault, J (2010). Bioactivities of black cumin essential oils and its main terpene from Tunisia. South African Journal of Botany. 76.2: 210-216. Doi.org/10.1016/j.sabj.2009.10.009.

8. British Pharmacopeia (1980). H. M. Stationary office, London, PA. 2:109.

9. Ding, L., Roland, P., Stephan, R., Song, Q and Hartmut, L (2009). Tau-muurolol Sesquiterpenes from the marine Streptomyces sp. M4911 and revision of the configuration of previously reported Amorphanes. Journal of Natural Products. 72.1: 99-101

10. Ejelonu, B. C., Lasisi, A. A., Olaremu, A. G and Ejelonu, O. C (2011). The chemical constituents of calabash (Crescentia cujete). African Journal of Biotechnology. 10.84:1963119636

11. Elias, T. S. and Prance, G. T (1978). Nectaries on the Fruit of Crescentia and Other Bignoniaceae. Brittonia. 30.2:175-181.

12. Fotié, J., Scott, B., Mara, L., Elias, G., Rukunga, G. and Nkenfack, A (2006). Lupeol Long-Chain Fatty Acid Esters with Antimalarial Activity from Holarrhena floribunda. Journal of Natural Products. 69.1:62-67.

13. Gang, D. R., Wang, J., Dudareva, N., Nam, K. H., Simon, J. E., Lewinsohn, E and Pichersky, E (2001). An investigation of the storage and biosynthesis of phenylpropenes in sweet basil. Plant Physiology. 125.2:539-555.

14. Gnangoran, B. N. (2012). Hypoglacaemic activity of ethanol leaf extract and fractions of Holarrhena floribunda (Apocynaceae). Journal of Medical and Biomedical Sciences. 1.3:46-54.

15. Goutarel, R (1964). Les Alcaloïdes stéroïdiques des Apocynaceae. Ed; Hermann, Paris. 1:166-171.

16. Jerkovic, I., Suste, M., Males, Z and Pilepic, K. H (2012). Essential oil composition of Prasium majus from Croatia. Natural Products Communication. 7.7: 931-932.

17. Jia, X. N., Zhang, Y. Y., Yang, Y. Z and Wang, J. X (2008). Extraction and GC-MS analysis of essential oil from leaves of Discocleidion rufescens. Zhong Yao Cai. 31.6: 845-847 (Chinese)

18. Joulain, D and Koenig, W. A (1998). The Atlas of Spectral Data of Sesquiterpene Hydrocarbons. E. B. Verlag, Hamburg. Pp 661

19. Letouzey, R (1972). Manuel de botanique forestière. Centre Technique Forestier Tropical 45 bis, Avenue de la BelleGabrielle, 94-Nogent s/Marne pp. 304-307.

20. Nii, H., Furukawa, K., Iwakiri, W and Kubota, T (2008). Constituents of essential oils of Actinodaphne lancifolia (Siev. Et. Zucc.) Meisn fruits, roots and leaves. Nippon Nogeikagatu Kaishi. 56.4: 261-268.

21. Onocha, P. A (1995). Phytochemical Investigations and Cytotoxicity of Anthocleista djalonensis (A. Chev.) and Newbouldia Laevis (Beaus) Seem. A Ph.D. thesis in Organic Chemistry, University of Ibadan, Nigeria.

22. Sousa, Z. L., Fernando, F., Conceicao, A. O., Silva, L. A., Rossi, M. H., Santos, J and Andrioli., L. H (2012). Biological activities of extracts from Chenopodium ambrosiodes Lineu and Kielmeyera neglecta Saddi. Ann Clin Microbiol Antimicrob. 11: 11-20.

23. Udobre, A. S., Nwafor, P. A. and Udoh, A. E. (2014). Analgesic effect of the methanol root extract of Holarrhena floribunda in albino mice. American Journal of Pharmaceutical Research. 4:148-153. 